\title{
Hanne Bruun
}

\section{Global tv-genre og komplekse \\ narhedsoplevelser \\ - en receptionsanalyse af \\ to daytime talkshows}

I teoretiske analyser af kulturelle globaliseringsprocesser bliver tv-mediet brugt som både forklaringsfaktor og eksempel på mediernes betydning for disse processer. Tv bliver dog ofte betragtet på et generelt niveau uden interesse for den genremæssige organisering af mediets udbud. Mediereceptionsanalyser har derimod vist, at genre er en meget væsentlig faktor $i$ seernes måde at relatere sig til mediet og dets indhold på, og artiklen præsenterer resultaterne fra en receptionsanalyse af unge danske kvinders sening af henholdsvis et amerikansk og et dansk daytime talkshow. På den baggrund diskuteres forholdet mellem genre, tv-mediet og kulturel globalisering. 
Jeanne: Kedeligt, det er for kedeligt, fordi der er ikke noget oplysning. Altså jeg kan godt lide at se noget, hvor jeg kan lære noget af det, og det gælder også omkring mennesker. Det kan være kræftpatienter, aids, hvad det nu er, ik' også, men hvor man kan lære noget. Men det der, det er jo noget snak, det er jo kun tidsfordriv og sladder ikke også, det mener jeg virkelig, det er kun tidsfordriv (Jeanne 27 år, SoS, DNS:2)

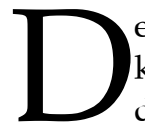
en unge kvinde udtrykker i det korte citat sin mening om det danske talkshow Det Ny Synnøve sammenlignet med det amerikanske talkshow Ricki Lake. Jeanne fremhæver, at det danske program, efter hendes mening, mangler nogle centrale kvaliteter, når det sammenlignes. Hendes udsagn er fra en receptionsanalyse af en gruppe unge, danske kvinders sening af daytime talkshows på dansk $\mathrm{tv}$, og kvinderne er specielt glade for Ricki Lake. Receptionsanalysen fokuserer på Ricki Lake-seriens attraktioner for kvinderne og deres oplevelse af det danske program.

Det Ny Synnøve blev sendt på TvDanmark i efteråret 1999, og var det første danske forsøg på at producere et daytime talkshow ${ }^{1}$. I denne form for talkshow inddrages såkaldt almindelige mennesker som gæster, og det emnemæssige fokus er privatlivets problemer. Gæsterne er dels i følelsesmæssig krise, dels konfronteres de med hinanden, med et studiepublikum af lægfolk og med en studievært. I Danmark er der gennem mange år blevet produceret massevis af talkshows, men både public service stationerne og de kommercielle stationer har undgået netop daytime talkshowet. Det er ikke denne artikels mål at undersøge grundene til, at dansk tv har valgt ikke at producere denne form for konfronta- tiv, offentlig terapi på tv. Men til sammenligning så har daytime talkshowet siden 1980'erne været meget talrig og populær i amerikansk tv, og i både Storbritannien og Tyskland har man med succes produceret daytime shows i en årrække (Krüger 1998). I Danmark har de kommercielle stationer TvDanmark,TV3 og 3+ gennem flere år sendt en række af de amerikanske shows som f.eks. Jenny Jones, Oprah Winfrey og Jerry Springer. Ricki Lake har været sendt siden 1996. Fordi danske seere gennem flere år har haft rig mulighed for at se daytime talkshows i tv, så kan man forvente, at de danske seere er ganske fortrolige med genren, trods fraværet af danske programmer inden for genren. De amerikanske daytime shows har i et vist omfang også været i stand til at tiltrække de danske seere, og især blandt teenagepiger og unge kvinder (1530 år) har Ricki Lake klaret sig godt, når man tager sendetidspunktet, den daglige sendefrekvens og at der er tale om udenlandsk fakta-tv i betragtning. I 1999, hvor Det Ny Synnøve sendes, havde Ricki Lake en gennemsnitlig rating til hovedudsendelsen kl. 17:15 - 18:15 på 84.000 og en share på $12 \%{ }^{2}$. Den danske serie begynder med en rating på 371.000 og en share på $14,8 \%$ til første afsnit d. 27.9., men derefter falder seertallet kraftigt, og serien ender på 90.000 og en share på 5,4\% til sidste program i serien d. 8.12. Den danske serie blev tilmed sendt kl. 21.55 22:45 på onsdage, så sendevilkårene for serien var på mange måder gode.

Alt i alt var seertallene til den danske serie et tegn på, at de danske seerne måske ikke var helt glade for Det Ny Synnøve, og det overordnede mål med receptionsanalysen var således at bevæge sig ned under tallenes overflade. Undersøgelsen ønskede først og fremmest at belyse relationen mellem en formodentlig velkendt transnational tv-genre og kulturel oprindelse. På baggrund af resultater 
fra undersøgelsen vil jeg i det følgende argumentere for, at seerne for det første opfatter daytime talkshowet som en del af en transnational tv-kultur. Genren indebærer en række forventninger af formog fremstillingsmæssig karakter, og den indebærer indholdsmæssige forventninger til den form for virkelighedsbearbejdning, som netop denne genre kan give. Genren har således en specifik kommunikativ funktion. Tv's genrer kan formodentlig betragtes som helt afgørende komponenter i struktureringen af en i den forstand global tv-kultur. At få indsigt i tv-genrernes æstetik og den kommunikative relation mellem genrerne og seerne kunne derfor være væsentligt i analysen af denne muligvis globale tvkultur. Men selvom daytime talkshowet kan betragtes som del af en formodentlig global tv-kultur, så peger undersøgelsens resultater for det andet på, at kulturel oprindelse spiller en meget væsentlig rolle for de kvaliteter, som de unge kvinder finder i den amerikanske serie. Artiklen vil derfor fremhæve den forestilling om national mentalitet og national identitet, som respondenterne udtrykker, og især vil den nytte, som disse forestillinger har i receptionsprocessen, blive fremhævet. Afslutningsvis vil tv's rolle i kulturelle globaliseringsprocesser bliver berørt med udgangspunkt i genre som en struktur i det, der kan kaldes kulturelle forventninger.

\section{Nærhedsoplevelser og tv's genrer}

John Tomlinson har i bogen Globalization and Culture fra 1999 en nyttig begrebsmæssig præcision i sin belysning af de elektroniske mediers formodede rolle i globaliseringsprocesser. Tomlinson skelner skarpt mellem, hvad han kalder global forbundethed (connectivity) fysisk på den ene side og nærhed (proximity) på den anden side. Forbundethed er re-

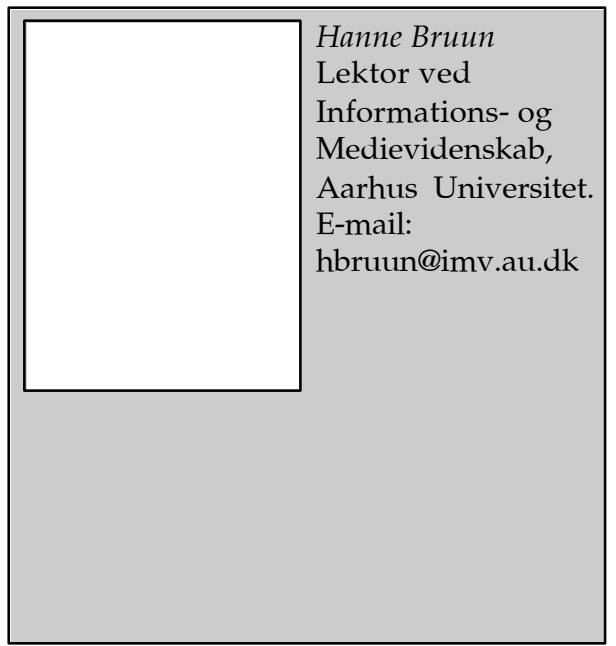

sultatet af en tid-rumkompression, som indebærer en reduktion af den tid, det vil tage at tilbagelægge afstand. Det kan både være repræsentativt f.eks. via transmission af information eller fysisk f.eks. via en flyrejse. Forbundethed og nærhed er ikke det samme, og nærhed bringer os ifølge Tomlinson ud over en empirisk forbundetheds niveau. Nærhed er således en bevidsthed om at være forbundet med resten af verden. Denne brug af ordet nærhed kan betragtes som Tomlinsons måde at begrebsliggøre de følelsesmæssige reaktioner hos mennesker, der oplever global forbundethed. Nærhed er dermed et resultat, når kulturel afstand så at sige er overvundet:

Proximity has its own truth as a description of the condition of global modernity and this is generally of either a phenomenological or a metaphorical order. In the first case it describes a common conscious appearance of the world as more intimate, more compressed, more part of everyday reckoning (...) In the second, it conveys the increasing immediacy and consequentiality of real relations metaphorically distanciated. Here the 
connections that affect our lives (...) are made sense of as though they really bring us into closer contact (Tomlinson 1999:3-4).

De elektroniske medier spiller en vigtig rolle i etableringen af en baggrund for disse nærhedsoplevelser hos mennesker. Tomlinson ser på flere kommunikationsmedier, men det er specielt hans interesse for tv's rolle, som skal fremhæves i denne forbindelse. Udgangspunktet er John Thompsons beskrivelse af massemediernes form for interaktion som ,medieret quasi interaktion", hvor manglende reciprocitet og det monologiske er de to grundlæggende kendetegn. Det er de fordele og begrænsninger, der findes i denne særlige form for interaktion mellem mennesker, som Tomlinson fokuserer på.

Hos Tomlinson er nærhed forbundet med resultatet af en mediemæssig praksis, og det må betyde, at form såvel som indhold derfor er afgørende, hvis der skal skabes en følelsesmæssig oplevelse af nærhed og samhørighed (closeness). Tomlinson argumenterer f.eks. for, at det i høj grad er via mediets måde at fortælle på, at der kan skabes nærhed og ikke en kvalitet, som automatisk findes i selve indholdet (Tomlinson 1999:179). Trods interessen for $\mathrm{tv}$-mediet og forestillingen om, at nærhed kan være resultatet af en mediemæssig iscenesættelse, så er der ikke nogen egentlig analyse hos Tomlinson af de mange forskellige fremstillingsformer, som findes i tv. Medieanalysen i bogen bevæger sig derfor på et meget overordnet og generaliserende niveau. Dog fremgår det indirekte via de eksempler, der tages op af Tomlinson til at illustrere tv's iscenesættelser, at Tomlinson betragter tv som et medie, hvor der er to specifikke former for iscenesættelse af tid og rum på færde. De to iscenesættelser skal i det følgende fremhæves, fordi de fører til eller er typiske i to forskellige roller, som mediet kan påtage sig i relationen til seerne. De to roller er derfor væsentlige i diskussionen af $\mathrm{tv}^{\prime}$ s evne til at skabe oplevelser af nærhed.

Den første rolle, som Tomlinsons eksempler indirekte fremhæver, er mediet $\mathrm{i}$ rollen som rapporterende medie, hvor mediet påtager sig at fortælle historier til seerne om forhold i en virkelighed uden for mediet selv. Det sker f.eks. i dokumentaren og i de fleste nyhedsindslag (Tomlinson 1999:171). Her bringes historier fra omverdenen så at sige "ind“ i seernes intimsfære eller domæne, men med tidsmæssig afstand mellem fortælletiden, det fortalte og receptionens tid. Den tidsog rummæssige iscenesættelse er i denne rolle populært sagt „dengang og der", og denne rolle kunne formodentlig danne basis for specifikke former for nærhedsoplevelser hos seerne, som Tomlinson dog ikke reflekterer over.

Den anden rolle, som Tomlinsons eksempler indirekte fremhæver, er tv i rollen som transmitterende medie. I den rolle er tv på besøg ude i virkeligheden, og mediet giver dermed seerne adgang til omverdenens begivenheder, som sker $i$ en samtidighed med receptionen. Men mediet er i denne selviscenesættelse ikke ansvarlig for det, der vises. Det er en rolle, som mediet indtager f.eks. i transmissioner fra sportskampe og i live-indslag i nyhederne, hvor der er et tidsmæssigt sammenfald mellem fortælletid, det fortalte og receptionens tid. Tomlinsons eksempel er mediedækningen af Prinsesse Dianas begravelse, hvor tv optrådte i rollen som transmitterende medie og skabte mulighed for nærhedsoplevelser af næsten rituel karakter på tværs af tid og rum (Tomlinson 1999:168-169). Som transmitterende medie kan tv's tids- og rummæssige iscenesættelse beskrives som et "nu og der".

Tv kan dog befinde sig i en tredje rolle i forhold til seerne, som Tomlinson ikke 
er orienteret mod hverken i sine eksempler eller i sin generelle mediebeskrivelse. Tv kan fungere som et virtuelt mødested, og det sker i f.eks. quiz'en og talkshowet, hvor mediet er selve begivenheden såvel som begivenhedens scene på én og samme gang, idet tiden og stedets enhed overholdes. Ved at optræde som virtuelt mødested forsøger mediet at skabe en oplevelse hos seerne af tidsmæssigt såvel som rummæssigt sammenfald mellem seernes domæne og mediet; et fælles „nu og her". Også i forbindelse med denne rolle kunne man formode, at tv kan tilbyde særlige former for nærhedoplevelser, som de to andre roller ikke kan give mulighed for.

Sammenfattende vil jeg med denne korte gennemgang argumentere for at betragte $t v$ 's forskellige oplevelsesmæssige tilbud som organiseret ved hjælp af de roller, som mediet kan iscenesætte sig selv i, og ved hjælp af genrer. Begge dele iscenesætter tid og rum på specifikke måder samt lægger sandsynligvis op til forskellige former for relationer mellem mediet og publikum og dermed forskellige oplevelsesmæssige modaliteter og forskellige former for nærhedsoplevelser.

Seerne har desuden, qua forbruget af tv's tilbud, et fintmærkende beredskab i forhold til tv's mange forskellige roller og genrer og i forhold til de forskelle, der måtte være, inden for den enkelte genre. Birgitta Höijer har i to undersøgelser påvist, at seerne har en række mere eller mindre bevidste vurderingskriterier og sorteringsmekanismer i forhold til tvmediets mange oplevelsestilbud (Höijer 1991 og 1996). Dels er forskellen mellem fiktion og fakta en sorteringsmekanisme, som seerne til fulde behersker, dels sorteres og vurderes der inden for f.eks. fiktionsformerne. Der skelnes eksempelvis uden besvær mellem populærkulturelle soaps og det, der i undersøgelsen fra 1996 betegnes som social-realistisk fiktion
(Höijer 1996:16).

Höijers undersøgelser viser dog samtidig, at den enkelte tv-produktions kulturelle oprindelse spiller en væsentlig rolle i de svenske seeres reception inden for den samme genre. I sammenligningen mellem to populærkulturelle soaps og i seernes oplevelse af social-realistik tv-dramatik er der tale om, at en højere grad af socio-kulturel genkendelighed og følelsesmæssig relevans adskiller de to svenske serier fra den amerikanske. Kulturel oprindelse indgår således som et vurderingskriterium for seerne på linie med vurderingen af en produktions genremæssige tilhørsforhold. Afhængig af genre synes den kulturelle oprindelse tilmed at skifte funktion. Den svenskproducerede populærkulturelle soap opleves som værende tættere på seernes virkelighed end den amerikanske og det på trods af, at begge serier af seerne bedømmes til at indeholde den mangel på realisme, som udgør den fremstillingsmæssige fællesnævner for den populærkulturelle soap (Höijer 1996:16). Resultaterne af Liebes og Katz' analyse af Dallas (Liebes \& Katz 1990) peger også på, at kulturel oprindelse spillede en rolle i receptionen af den succesfulde soap opera. Selv om Dallas ligesom de fleste populærkulturelle produkter var spækket med genkendelige og fundamentale normative konflikter mellem mennesker, hvilket kunne forklare en stor del af seriens gennemslagskraft uden for USA, så aktiverede serien også en række tolkningsmæssige skemaer om kulturelle forskelle. De mange ikke-amerikanske fokusgrupper udtrykte i deres reception af Dallas stærke holdninger til amerikanere og seriens amerikanskhed. Serien blev kort sagt set gennem forskellige kulturelle filtre. Liebes og Katz konkluderer, at jo tættere seerne var på USA, des mere distance havde de til seriens "realisme", idet den indgik $i$ en sammenligning med seernes egne 
erfaringer (Liebes \& Katz 1990:16).

Sammenfattende kan man sige, at seernes vurderingskriterier således både har udspring i en transnational tv-kultur, idet de har en erfaring med en række genrer inden for denne kultur. "The continuous rehashing", som Ien Ang kalder det (Ang 1996:16), af disse relativt konstante genrer og formater så som politiserien, situationskomedien, quizog gameshowet osv., har givet seerne mulighed for at opnå denne viden. Desuden har seernes vurderingskriterier tilsyneladende udspring i nogle sociale erfaringer, som spiller en rolle i oplevelsen af denne transnationale $t v-k u l t u r$.

\section{Talkshowet: \\ Selskabelighed og usikkerhed}

Som beskrevet, så påtager tv sig rollen som virtuelt mødested i talkshowgenren, og forsøger derved at skabe en „nu og her"-oplevelse for seerne ${ }^{3}$. Men ud over denne iscenesættelse af tid og rum, så finder der en uhyre væsentlig iscenesættelse af quasiinteraktionen mellem program og seere sted. Der er tale om, at der i genren er en intensiv insisteren på, at skabe en oplevelse af kontakt mellem program og seere, og valg af såvel som iscenesættelsen af studieværten er et væsentligt aktiv i etableringen af kontaktoplevelsen. Resultatet er, at en meget stor del af indholdet i genren netop er kontaktoplevelsen i sig selv. Talkshowet inkarnerer på den måde to grundlæggende kendetegn ved selve tv-mediet. Tv er for det første i stand til at sende ikke-fiktive levende billeder direkte, hvorved mediet adskiller sig fra filmen og radioen. Mediet er for det andet kendetegnet ved at være en offentlig tilgængelig henvendelse til de mange, som sendes ind i og bruges i den enkelte modtagers private rum, tilmed er tv i Danmark i høj grad fritidens medie. Mediet må derfor finde henvendelsesformer, som kan passe til denne på én gang offentlige og private situation. Disse to grundforhold, som talkshowet inkarnerer, har jeg sammenfattet ved hjælp af begreberne usikkerhed og selskabelighed (Bruun 2000b: 251), som er de to modsatrettede kræfter i et hvert talkshow. De to begreber skal derfor kort præsenteres:

Selskabelighed er karakteristisk for den form for kontaktoplevelse, som genren søger at etablere med sine seere, og det betyder, at selve samværet mellem mennesker er en meget væsentlig del af det manifeste indhold i et talkshow. Selskabelighed (sociability) har den tyske sociolog Georg Simmel beskrevet som en særlig form for samvær mellem mennesker, hvis middel og mål er deltagernes personlighed og menneskelighed (Simmel 1910:130). Men ifølge Simmel har selskabelighed som samværsform mellem mennesker samtidig svært ved at rumme det private og det individuelle (Simmel 1910:130). Det betyder, at et selskabeligt samvær må vægte det, der binder mennesker sammen og understreger fællesskabet. Det private hos den enkelte deltager - f.eks. voldsomme aggressioner, dyb sorg og åbenlyse følelsesmæssige sammenbrud - vil derfor være destruktivt for selskabeligheden. Der må således holdes en hårfin balance mellem det formfuldendte og menneskeligt sociale og det individuelle og menneskeligt private, for at selskabeligheden kan opretholdes som samværsform. Men det er væsentligt at understrege, at selskabelighed ikke nødvendigvis udelukker bestemte indholdsmæssige temaer i samværet mellem mennesker. Det er i meget høj grad et spørgsmål om, hvorvidt det deltagerne siger og gør er med til at bevare selskabelighed som situationsdefinition, eller er med til at erodere den og eventuelt omdefinere situationen. Den specielle form for kontakt, der præger genren, kan føre til parasociale relatio- 
ner mellem seerne og specielt studieværten, og det kan dermed gøre selve samværet med denne til en meget vigtig attraktionsværdi i bestemte serier (Horton \& Wohl 1956). Usikkerhedselementet er knyttet til, at talkshowet sendes live eller live-on-tape, og det er dermed tv uden sikkerhedsnet, idet der enten ikke kan redigeres eller tages om, eller kun i begrænset omfang, hvis illusionen om live-tv skal opretholdes. Dermed rummer genren en mulighed for, at seerne kan få en inciterende oplevelse af uforudsigelighed, uberegnelighed og spontanitet. Usikkerhedselementet kan kort sagt bringe et element af kaos og farlighed ind i det selskabelige samvær og dermed true selskabeligheden eller skabe brud med denne form for samvær mellem mennesker. Grænseoverskridelser til det private kan blive resultatet at usikkerhedselementet, og grænseoverskridelserne kan skabes både ved den måde, der tales på og i den måde, man opfører sig på i talkshowet.

I de amerikanske daytime talkshows er der stor vægt på de potentielle brud med selskabeligheden. Der er hele tiden en mulighed for, at gæsterne og studiepublikum overskrider den grænse til det private, som selskabeligheden sætter. Selskabelighedens vægt på samvær og fællesskab, og den pænhed og kontrollerethed, det kan resultere i, er dermed i konstant risiko for at erodere. Usikkerhedselementet er dermed så højt prioriteret, at muligheden for, at kaos, ubehag og ansigtstab bliver en væsentlig del af programmerne inden for subgenren, absolut er tilstede. Den afgørende dramaturgiske drivkraft er de medvirkende gæsters krisetilstand: Daytime talkshowet emnemæssige fokus er som sagt på privatlivets problemer, som gæsterne sidder i til halsen, idet de har en alvorlig moralsk konflikt indbyrdes, som de ikke selv kan løse. De har ikke lagt proble- merne bag sig eller bearbejdet noget som helst. Bearbejdningen og løsningen af problemerne skal netop finde sted i programmet. På den måde er selskabelighedens vægt på samvær mellem mennesker, socialitet og kontrollerethed i høj grad tilstede.

Udgangspunktet for receptionsanalysen var således en tese om, at spillet på selskabelighedsbruddene, og dermed ansigt, på den ene side var helt afgørende for lysten til at se denne type talkshow. Men brud med selskabeligheden var formodentlig også det, der på den anden side kunne gøre seerne utilpasse ved at se denne form for talkshow og eventuelt ved deres egen lyst til at se den. Subgenren spiller netop på spændingen mellem såvel tryghedsskabende, fællesskabs- og samværsorienterede tangenter som på utryghed og udskillelsesorienterede tangenter. Om det faktum, at de to serier var henholdsvis en amerikansk og en dansk serie, spillede nogen rolle i den form for relation, som seerne havde til serierne, var derfor også det afgørende spørgsmål i undersøgelsen. Hvilken funktion havde den enkelte series kulturelle oprindelse i dette formodede fascinerende og muligvis provokerende tilbud til seerne, og var der tale om en sammenhæng med netop daytime talkshowet som genre?

\section{Undersøgelsesdesign og interviewanalyse}

Det metodiske udgangspunkt for at belyse undersøgelsens spørgsmål har været kvalitativ receptionsanalyse med det individuelle semistrukturerede interview som redskab ${ }^{4}$. Respondenterne i undersøgelsen var alene unge kvinder, og det valg var begrundet i den seerprofil, som Ricki Lake-serien har, samt en formodning om, at det også ville være de seere, som ville være interesserede i det danske program Det Ny Synnøve. På grund af begge seriers relativt lave seertal var det et nød- 
vendigt praktisk valg at rekruttere deltagere via undervisningsinstitutioner. Jeg valgte to forskellige institutioner på en formodning om, at uddannelsesmæssige interesser og niveau afspejler individuelle livsomstændigheder og værdier, hvilket igen kunne have en stor betydning for receptionen af denne form for tv-talkshow: Det drejede sig om en købmandsskole med elever i gang med en Højere Handelseksamen $(\mathrm{HH})$, og det drejede sig om en gruppe elever i gang med den etårige uddannelse til social- og sundhedsassistent (SoS). Begge institutioner ligger i Århus, og alle deltagerne i undersøgelsen boede $\mathrm{i}$ Århus, dvs. det var alene unge kvinder fra en stor provinsby, som undersøgelsen fokuserede på. Det var således kombinationen af køn, alder og regionalitet, som udgjorde fællesnævneren blandt de danske kvinder, hvorimod livsstil formodedes at være den faktor, som kunne tænkes at give anledning til forskelle mellem de to grupper $(\mathrm{H}$. Dahl 1997)5 . Aldersmæssigt forsøgte jeg at opnå en vis spredning, da man kunne formode, at de moralske diskussioner i begge serier ville blive oplevet forskelligt afhængig af modenhed og livserfaring. Der blev derefter foretaget individuelle interviews med ni kvinder $\mathrm{i}$ alderen 18 til 32 år Deltagerne blev interviewet to gange af ca. $11 / 2$ times varighed i deres hjem. Jeg havde desværre et frafald på to personer i anden omgang, én fra $\mathrm{HH}$ gruppen og én fra SoS-gruppen, så mit analysemateriale er 16 interviews i alt: ni Ricki Lake -interviews og syv Det Ny Synnøve -interviews.

Interviewene var lagt tilrette efter at få afdækket selskabelighedsbruddenes betydning for de interviewedes oplevelse af de to programserier samt at få indblik $i$, hvilken betydning seernes erfaring med daytime talkshowet generelt og Ricki Lake i særdeleshed havde. Desuden vil jeg understrege, at der ikke var intentio- ner om at spørge til den kulturelle oprindelse, men lade kvinderne tematisere dette, hvis de fandt det væsentligt. Alle på nær én gjorde det, og temaet lå klart yderst på tungen hos kvinderne. Undtagelsen var en kurdisk-tyrkisk kvinde på 20 år, som har boet i Danmark i 10 år .

\section{Daytime talkshows og seerne}

I det følgende vil jeg præsentere hovedresultaterne fra undersøgelsen, og to overordnede konklusioner vil strukturere fremstillingen ${ }^{7}$. For det første peger undersøgelsen - måske ikke særlig overraskende - på, at daytime talkshowet synes at være en del af en for seerne velkendt tv-kultur, som seerne har udviklede og differentierede kvalitetskriterier og vurderingsredskaber i forhold til. De to serier opleves på en sådan baggrund, og det har en række konsekvenser for det danske program, som ikke lever op til de kvalitative forventninger, som seerne har til den denne form for $t v$, der er etableret via seningen af Ricki Lake og de andre amerikanske shows. De grundlæggende genremæssige rammer af form- og indholdsmæssig karakter, som de nationale udfyldninger må forholde sig til, er dermed sat af den amerikanske tv-industri og denne tv-industris evne til at skabe følelsesmæssig nærhed og relevans i produktionerne. For det andet peger undersøgelsen på, at den kulturelle oprindelse spiller en uhyre væsentlig rolle i oplevelsen af de to serier, og i forhold til den danske serie placerer den kulturelle oprindelse seerne i et dilemma mellem følelsesmæssig og social nærhed. Programmerne aktiverer desuden en række forestillinger hos seerne om amerikanskhed i forhold til danskhed og dansk nationalmentalitet, som har en central betydning for de kvaliteter, som daytime talkshowet har for seerne. Disse forestillinger udgør tolkningsskemaer for oplevelsen af de to serier, og de fungerer vel at mærke samti- 
dig med, at de to serier opleves som del af en tv-kultur, som på mange måder har transnational karakter.

\section{Provokationer og kvaliteter}

De danske seeres reception af Ricki Lake viser, at der er to helt afgørende kendetegn, som synes at udgøre daytime talkshowgenrens basale tiltrækningskraft i forhold til seerne: Det er for det første selskabelighedsbruddene og for det andet, at der er tale om en fakta-genre.

Ricki Lake er for det første en følelsesmæssig provokation, idet serien sætter menneskelig ære og værdighed på spil, dvs. ansigt er konstant på spil. Det sker ved hjælp af de brud med selskabeligheden, som viste sig at være centrale for seriens tiltrækningskraft. Ricki Lake fremstår dermed i høj grad som et forum for grænseoverskridelser til det private. Det betyder, at specielt gæsterne i programmet opleves som pinlige ${ }^{8}$. Deres udsagn, opførsel og ikke mindst deres udseende er upassende i forhold til den situation, de befinder sig i. Der er for det første udsagn, der for kvinderne overskrider normer for ansigtsbevarende selvbiografi. Det resulterer grundlæggende i en gysende og forarget evaluering af, at nogen vil tillade sig selv at fortælle den slags $i$ et $t v$-program og dermed afsløre private sider af sig selv. I det screenede program fortæller mødre om problemer med deres teenagebørn, og programmets emne er en moralsk konflikt mellem mødre og de unge, der drejer sig om de unges sexliv. En af respondenterne, Jette, beskriver en mors behandling af sin søn i programmet på følgende måder:

Jette: Jamen hun er jo meget, meget bestemt, men hun sætter ham jo også i en pinlig situation synes jeg ved at sige, at han bruger sutteklud, og sutter på tommeltot som 13-årig, synes jeg. Det må være lidt pinligt, synes jeg, og det synes jeg er meget, meget flovt, at hun går ind og siger sådan noget. (Jette 22 år HH, RL:10)

Jette reagerer på to ting. Dels reagerer hun på, at moderen viser nogle sider af sønnens personlighed frem i situationen, som er pinlige for ham at få frem i et program, hvor hans sexliv er årsagen til konflikten mellem mor og søn. Dels reagerer Jette på selve det faktum, at moderen kan finde på at fortælle den slags. Hendes udsagn afslører dermed sider af hendes person, som peger på, at hun ikke har styr på sig selv og sit forhold til sønnen, trods det umiddelbare indtryk af viljestyrke og kontrol. Hos en anden respondent, Jeanne, rammer forargelse alle mødrene i det screende program, som udsætter deres børn for en brutalitet, der får børnene til at bryde følelsesmæssigt sammen og dermed tabe ansigt i programmet:

Jeanne: jeg synes, at det er for dårligt, der må sgu' være noget galt, hvis man som forældre er nødt til at få dem ind for åben skærm, for det er ydmygende. (...) mange af dem er lige ved at tude, de ved ikke hvad de skal sige (Jeanne 27 år, RL:2)

Det er dog for det andet i lige så høj grad karakteristisk for seernes reaktioner, at de hæfter sig meget ved, hvordan det verbale fremføres og hvordan deltagerne ser ud. Seerne hæfter sig altså ikke alene ved, hvad der bliver sagt mere eller mindre direkte. Det er specielt konfrontationer mellem gæsterne og den fremvisning af aggression, det som regel medfører, som kvinderne finder provokerende. Aggressioner er en fremvisning af private følelser, som er destruktive for det samvær og det fællesskab, som programmerne søger at fastholde og opretholde. Kombi- 
nationer mellem aggressiv adfærd og en fysisk fremtoning, som opleves som et udtryk for manglende selvkontrol, er derfor i særdeleshed provokerende og tiltrækkende. Ane udtrykker det således:

\begin{abstract}
Ane: (...) man kan da ikke lade være med at grine, men det er også, men de er også tit..., OK jeg ved godt, at det ikke er pænt sagt, men tit så er det altså også bare big mama'er der alle sammen er inde ikk' (latter). Og dem som står og råber og skriger, det hele det står jo og svinger på dem ikk'! og de er bare så grimme ikk' og kiksede mange af dem. Jeg ved godt det ikke er pænt sagt men... (Ane 20 år HH, RL:13)
\end{abstract}

Fryden ved gæsternes groteske udseende spiller alt $i$ alt en væsentlig rolle for kvinderne og beskrives eksempelvis af Brit som den altdominerende grund til, at hun selv ser Ricki Lake. For Brit er det det eneste grund, som hun mener, at man kan have, til at se serien:

\begin{abstract}
Brit: Jeg tror bare man vil have noget at grine af, man vil se nogle sjove typer, f.eks. en mor der kommer ind i en stram lyserød kjole og kæmpe permanentet hår, der er ved at dø om ørene på hende. Det er sådan noget man bare vil se og så sidde og grine af hende. Hvordan kan hun selv tage det seriøst, det hun sidder og siger ikk'. Så er det egentlig fuldstændig underordnet, om det er hendes mand, der har været hende utro, eller hendes søn har 3 børn og han er 15 år eller sådan noget. Det tror jeg egentlig man er ligeglad med. (Brit 18 år HH, RL:6)
\end{abstract}

Brud med selskabeligheden betyder, at en meget væsentlig del af indholdet i dette show for recipienterne er fremvisninger af kontroltab og ansigtstab hos mennesker, som har store sociale og psykologiske problemer. Brud med selskabeligheden er så følelsesmæssigt provokerende, at det kan få kvinderne til at tvivle på den faktuelle ramme inden for hvilken Ricki Lake og daytime showene ses. Kun Jerry Springer er så outreret, at serien opleves som for iscenesat til at kunne bestå. Genren udsættes således for den realitetsprøvning, som også andre faktuelle genrer udsættes for (Höijer 1991), og det er meget væsentlig for kvinderne, at der netop er tale om fakta og ikke fiktion. Jette fra $\mathrm{HH}$-gruppen udtrykker det på denne måde, når hun forsøger at forklare, hvordan serien på det punkt adskiller sig fra de oplevelser af problembehandling, som fiktion giver hende:

Jette: man får egentlig at vide at verden ikke er så vidunderlig, som vi bliver vist i mange film. Altså her får man virkelig at se, hvordan man egentlig kan have det ikke. Altså man har virkelig problemer. I film der er det jo simpelthen så rosenrødt tit og ofte ikke også, men her der får man virkelig at se, at der er sgu' mange, der har nogle virkelige store problemer. (Jette 22 år HH, RL:15)

Kombinationen mellem selskabelighedsbrud og fakta-kontrakt betyder, at seernes udsagn om Ricki Lake indeholder en grundlæggende selvmodsigelse: På den ene side er det brud med selskabelighedens grænser, som er det provokerende forargelige ved serien, hvilket giver seerne en oplevelse præget af væmmelsesfryd. På den anden side er selskabelighedsbruddene en væsentlig motivation for overhovedet at se serien og årsagen til de kvaliteter, som serien indehol- 
der for seerne. Ricki Lake er uhyre velegnet til en bearbejdning af konfliktfyldte moralske normer i følelsesmæssigt vigtige sociale relationer, som er genkendelige for seerne. Hvert program i serien koncentrerer sig så at sige om én social relation. Det kan som i det screenede program være forholdet mellem mødre og teenage-børn, eller det kan være andre vigtige relationer som f.eks. forholdet mellem søskende eller kærester. Pointen er, at fastholdelse af en social relation gør denne til en del af programmet indhold, trods en måske bizar moralsk konflikt i det enkelte program. De moralske konflikter truer nemlig de vigtige sociale relationer, som dermed er i fare. Selskabelighedsbruddene giver netop adgang til og indblik i, hvor store problemer gæsterne har i spændingsfeltet mellem normtilpasning og normafvigelse. Men det er ikke svar på moralske konflikter, som seerne ønsker. Trods Ricki Lake-seriens skarptskårne helte- og skurkeroller og moralisme, så er det ikke de sider ved serien, som kvinderne fokuserer på. Derimod fokuseres der på de elementer i serien, som kan holde en normbearbejdende og -debatterende proces åben og tilgængelig. Ricki Lake har tre centrale kvaliteter at tilbyde seerne, som kan bruges til det formål. De tre kvaliteter drejer sig for det første om 1: oplevet oprigtighed 2: om oplevelse af hjælp og løsninger til gæsterne og seerne og endelig om 3: en psykologiserende position med mulighed for at afprøve og øve seernes egne evner $i$ rollen som psykologisk og social iagttager.

Oplevet oprigtighed er nødvendig for at gæster, studiepublikum og studievært har den fornødne troværdighed, der gør dem brugbare i den normbearbejdning, som serien bruges til af kvinderne. Af den grund foretrækker kvinderne de gæster og de medlemmer af studiepublikum i serien, som hverken fremstår som fanget i stålsat moraliseren eller moralsk ligegyldighed. Det er den type deltagere, som bedst synes at imødekomme kvindernes egne oplevelser af vanskelighederne i de sociale relationer, som serien tematiserer. Gråd og bevægethed er derfor tegn på, at der er tale om oprigtighed hos gæsterne, og en vilje til at ville redde den sociale relation. Aggressioner derimod opleves som lig med moralsk fortabelse, og dermed en manglende vilje til at ville redde den vigtige sociale relation, som trues af den moralske konflikt. Studieværten skal i relationen til gæster, studiepublikum og seere balancere i spændingsfeltet mellem den totale normtilpasning og normafvigelse. Studieværten Ricki Lakes evner på dette felt er for de fleste af kvinderne grunden til at se serien: Hun opfattes som en ekstrem positiv figur, der kender de konflikter, som gæsterne typisk er fanget i, men hun er $\mathrm{i}$ stand til at beherske disse konflikter. Hun har dermed en medierende funktion og kan derfor forsøge at hjælpe gæsterne igennem problemerne, men vel at mærke kun de gæster, som selv udviser en vilje til at ville hjælpes. Over for såvel de moralsk fortabte og moralisterne har hun derfor ifølge kvinderne retten til at være skrap, irettesættende og drillende. Kun to af de interviewede, som begge er fra HH-gruppen, er kritiske overfor Ricki Lake og opfattede hende som dobbeltmoralsk og kynisk udnytter af andres problemer i et kommercielt øjemed. At se på dette kyniske spil er for én af kvinderne grunde til at se serien. Trods en lille forskel i oplevelsen af studieværten, så betyder fokuseringen på selve bearbejdningen af konflikter i spændingsfeltet mellem norm og normafvigelse til gengæld, at alle interviewede afskyr de psykologiske eksperter, som serien ofte inddrager. Dette element i serien tilbyder alene en løsning og et svar, der genopretter normen, og eksperterne anerkender dermed ikke den flertydighed, der er i spæn- 
dingsfeltet, og hvad det indebærer for normbearbejdningen.

Den anden væsentlige kvalitet ved serien er, at serien kan hjælpe mennesker med problemer. Otte ud af de ni interviewede kvinder giver udtryk for, at serien tilbyder hjælp og løsninger. Studieværten er helt konkret i rollen som godgørende figur, idet hun med de penge, som programmet tjener ind qua sin popularitet, giver økonomisk hjælp til gæsterne. Der tales derfor meget om programmer, hvor aids-syge, kræftramte børn, overvægtige og narkomaner har fået tilbudt og modtaget behandling og hjælp. Men ikke alle skal i følge kvinderne have hjælp. Det skal kun de gæster, som udviser de oprigtige følelser og dermed har en troværdighed for seerne i den normbearbejdning, som serien tilbyder kvinderne. Man kan vælge at se fokuseringen på, at serien hjælper gæsterne og løser problemer som en legitimering i forhold til intervieweren og i forhold til seeren selv: Fokuseringen kan være med til at retfærdiggøre, at man finder det interessant at se på en fremvisning af andres ansigtstab og ulykke. Denne fremvisning bliver jo netop forudsætningen for, at de kan hjælpes. Men det er samtidig et uhyre livsbekræftende krav til serien, at den skal afhjælpe den elendighed, som den selv fremstiller. Kvinderne er derfor meget glade for, at der i det enkelte program er "happy-end" historier, hvor hjælpen så at sige redder den vigtige sociale relation, som den moralske konflikt truer.

Den tredje gennemgående kvalitet, som serien tilbyder, er en psykologiserende position for seerne $i$ forhold til alle medvirkende i serien. Seernes forholden sig til den moralske konflikt går på kryds og tværs af de konfrontationer mellem helte- og skurkepositioner i serien, som der ellers er langt op til. Interessen er snarere at slutte sig til, hvad der er det egentlige problem og dermed årsagen til, at den sociale relation er truet. Derfor er alle meget hurtige til at opsnappe og gennemskue de bidder af information om eksempelvis gæsternes baggrund, som ikke er direkte forbundet med den moralske konflikt. Der er dog en markant forskel mellem de to grupper kvinder, idet den psykologiserende interesse for SoS-kvinderne i høj grad er bundet sammen med at placere skylden og finde frem til den egentlige skurk. Den psykologiserende interesse fra $\mathrm{HH}$-gruppens side er mere analytisk orienteret, hvor man placerer sig selv i rollen som neutral iagttager. Men for begge grupper giver Ricki Lake mulighed for at være i rollen som den overskuende og gennemskuende, og serien er på denne måde tv-i-øjenhøjde for kvinderne, idet den tilbyder dem rollen som kompetente psykologiske og sociale iagttagere. Igen her bruges de psykologiske eksperter som springbræt, idet de "gode råd" ofte forlængst er givet af kvinderne selv, før eksperterne inddrages til sidst i programmet. Kvinderne har derfor mulighed for at opleve sig selv som værende eksperterne intellektuelt overlegne.

Selskabelighedsbruddene, faktakontrakten og de tre kvaliteter, som seerne dermed finder i den amerikanske serie, er i meget ringe grad til stede i oplevelsen af det danske talkshow Det Ny Synnøve. Det altoverskyggende problem for kvinderne er, at de danske gæster ikke har nogen rigtige problemer. Et rigtigt problem er ifølge kvinderne noget, som netop truer en følelsesmæssig værdifuld social relation. I den danske serie er der med andre ord ikke nogen moralsk konflikt, som truer en vigtig social relation og medfører de næsten eksistentielle problemer, som kan findes i det amerikanske program. Der er derfor ikke baggrund for de selskabelighedsbrud, som er afgørende for daytime talkshowets tiltrækningskraft. Det er grunden til, at alle kvinderne finder den danske serie både 
kedelig og dårlig. Ellen fra SoS-gruppen beskriver oplevelsen af serien som helhed ved at tage udgangspunkt $i$ to unge pigers påståede venindeforhold i det screende program:

Ellen: Ja, altså rent ud sagt så ragede det mig faktisk ikke! Der var ikke stof i det, det var kedeligt, det var latterligt. Jeg har det også sådan, at de to piger, der havde været veninder i to år, det er ikke det, som jeg kalder veninder. Selvfølgelig kan man være veninder og man kan sidde og græde, som de sidder og siger. Men jeg har altså en veninde, det er hende, som jeg betror mig til i alt, vi har også været veninder siden konfirmationsalderen (Ellen 32 år SoS, DNS:8).

Manglen på „rigtige problemer" er det ene af de to gennemgående kritikpunkter i forhold til den danske serie. Det andet er, at serien er forvirrende og grundlæggende er det svært at finde ud af, hvad de enkelte afsnit handler om. Grunden til dette er, at den danske serie ikke forankrer sine moralske konflikter i én gennemgående social relation i det enkelte afsnit. Det betyder at serien skifter social relation fire til fem gange i hvert afsnit, og dermed forhindrer serien seerne $i$ at kunne interessere sig for og udforske netop den sociale relation. Den kvalitative undersøgelse kan således være et bidrag til en forklaring på, hvorfor seriens seertal styrtdykkede. Men selvom der kort og godt er tale om et program, som skuffer fælt, da det hverken er følelsesmæssigt interessant eller provokerende, så er Det Ny Synnøve alligevel i stand til at placere seerne i et dilemma: Serien leverer ikke det, der forventes og ønskes af et daytime talkshow, men at serien er dansk, er også et helt særligt problem. Den kulturelle oprindelses be- tydning for de to seriers kvaliteter for seerne er derfor uhyre væsentlig.

\section{Amerikanskhed som psykologisk buffer}

Den anden hovedkonklusion, som undersøgelsen af de to daytime talkshows giver anledning til, er, at Ricki Lake-series trods sin følelsesmæssige provokation forbliver ufarlig for kvinderne. At serien er amerikansk bruges som en psykologisk buffer af alle undtagen den kurdisk-tyrkiske kvinde. Selvom kvinderne registrerer, at grænser for ære og værdighed overskrides i serien, så er det ikke en grund til at afvise serien. Tværtimod kan den form for opførsel, der fremkommer på grund af bruddene, forklares med, at der er tale om et amerikansk program, og amerikanere er anderledes. Det amerikanske holder serien på en sådan afstand, at den bliver brugbar til både normbearbejdningen samt til kulturel selvbekræftelse. Helene fra $\mathrm{HH}$-gruppen udtrykker amerikanskhedens funktion for hende således:

Helene: det er jo fedt at sidde og se på det på afstand

I: Hvad er det der gør at det ikke kommer tæt på, synes du?

Helene: For det første så er det jo en helt anden samfundsklasse, synes jeg. Det kommer ikke tæt på, fordi det ville bare ikke foregå hjemme, det ville aldrig kunne ske herhjemme. Det er simpelthen så amerikansk synes jeg. Jeg tror også, at det er derfor, at (Det Ny) Synnøve halter, det bliver svært at leve op til. (Helene 27 år HH, RL:2).

Som det også fremgår af citatet, så er der hos specielt HH-gruppen tale om en glidende overgang mellem brugen af det amerikanske og brugen af andre former for forskelle af klassemæssig eller psy- 
kologisk art. Dette er langt hen ad vejen et resultat af seriens dramaturgiske og tematiske opbygning, der skaber et behov for at tage følelsesmæssig afstand på én eller anden måde. Alle kvinderne oplever dog serien som en direkte afspejling af, hvordan det amerikanske samfund, amerikanerne og amerikansk moral er. Serien opfattes kort og godt som et udtryk for amerikansk nationalkultur og mentalitet. Det dominerende tema er, at de amerikanske moralske værdier både er puritanske og hysteriske. Værdierne er dermed egentlig årsagen til konflikterne i de sociale relationer ifølge kvinderne. Over for denne restriktive moral, er den danske moral af en langt højere standard, idet dansk afslappethed og tolerance er forklaringen på, at der ikke findes den samme slags konflikter. På den anden side er det amerikanske også ensbetydende med moralsk opløsning, med vold samt et socialsystem, der er betydelig dårligere end det danske. Alt i alt fastholdes serien ved hjælp af det amerikanske i et slags eksotisk limbo, som er med til at styrke seriens brugbarhed.

Behovet for en psykologisk buffer kunne forudsættes fraværende i forholdet til den danske serie, men den kulturelle oprindelse betyder i dette tilfælde tilsyneladende, at meget lidt bliver meget pinligt. På nær den kurdisk-tyrkiske kvinde er alle noget foruroliget over at se landsmænd af begge køn optræde i et daytime talkshow. Brit fra $\mathrm{HH}$-gruppe formulerer det således:

Brit: det kan godt være, at det er fordi, det kommer lidt tæt på, når det er dansk. Man bryder sig måske ikke om at se danskere sidde og skeje sådan ud, fordi man føler måske at det er lidt af en selv et eller andet sted. Det er måske lidt skræmmende at se, at vi nu også er hoppet over på den vogn der ikke. (Brit 18 år HH, DNS:1)

Oplevelsen kan ikke tilskrives selskabelighedsbrud i den danske serie, der bare kommer i nærheden af, hvad der foregår i den amerikanske serie. Men Det Ny Synnøve kan, på trods af at serien ifølge kvinderne både er kedelig, tam og kun indeholder trivialiteter, alligevel provokere. Det får nogle af kvinderne til at forsøge sig med det regionale som psykologisk buffer, idet man forsøger sig med forskellen mellem jyder og københavnere som forklaring:

Lisbeth: de (Lisbeths venner) siger egentlig ikke noget godt om det (Det Ny Synnøve), de synes det er mystisk, eller de der er med, det er typisk københavnere mand, altså de skal have noget opmærksomhed ik' (med forsøg på københavner-accent), og sådan kører duren lidt, så det er lidt komisk, så det har lidt med at fange københavnere! (Lisbeth 19 år HH, DNS:2).

For Ane er både det regionale og sammenligningen amerikanere og københavnere ved at bryde sammen som psykologisk buffer, da nogle af gæsterne i programmet kommer fra byer meget tæt på Århus:

Ane: det er måske også fordi det netop kommer så tæt på én, når nu det er Danmark ikke, og så Silkeborg og Skanderborg! Det bliver tættere og tættere på ikke, altså jeg tror ikke, jamen du tager bare afstand fra det: nå ja amerikanerne de er jo også åndssvage ikke, hvad kan de ikke finde på altså, så jeg tror måske man tager lidt afstand fra det (Ane 22 år HH, DNS:8-9).

Det danske har således en ret væsentlig 
betydning, men serien opleves dog stadig som uhyre mislykket og kedelig. Jeanne fra SoS-gruppen udtrykker det således:

Jeanne: jeg synes Ricki Lake er lidt mere prof., altså hun er noget bedre, hun har noget mere psykologi med i det, det synes jeg. Det er som om, hun har taget en psykologisk uddannelse, der er lidt mere psykologi i Ricki Lake, end der er i Synnøve, og der kunne hun sgu' godt lære noget! (Jeanne 27 år SoS, DNS:6).

Om et vellykket dansk daytime talkshow ville kunne tiltrække og fastholde seerne er et spørgsmål, som undersøgelsen ikke kan svare på, men måske kan regionale, klassemæssige eller andre former for oplevede dikotomiske forskelle fungere på samme måde som den nationalkulturelle, hvis det er nødvendigt med en psykologisk buffer. Måske er dikotomierne et nødvendigt kategoriseringsredskab, men indholdet i dikotomierne kan være mere ustabilt (Morley 2000:244), sådan som glidningen mellem nationale forskelle og klasseforskelle i Ricki Lake og den regionale forskel mellem jyder og københavnere i Det Ny Synnøve kunne tyde på9 . I hvert fald kan man ikke konkludere på baggrund af denne undersøgelse, at daytime talkshows på dansk vil være dømt til at mislykkes, da ingen danske seere vil have lyst til at se danskere fremstillet på den måde, som en vellykket realisering af genren daytime talkshow fordrer. Dertil er det danske program simpelthen for dårligt.

\section{Danskhed og normativ balance}

At Ricki Lake-serien opfattes som et udtryk for amerikansk nationalkultur og mentalitet frem for udtryk for daytime talkshowets genrekarakteristika og dra- maturgi betyder, at denne form for $\mathrm{tv}$ ses gennem nogle ganske faste tolkningsskemaer. Disse tolkningsskemaer drejer sig i høj grad om en bestemt opfattelse af danskhed og danskere, som kommer til udtryk i kvindernes oplevelse af de to serier. Med udgangspunkt i Bruhn Jensens undersøgelse af nationale publikummers oplevelse af udenrigsnyheder på tv (Bruhn Jensen (ed.) 1998), så er der blandt danskere tilsyneladende en række tolkningsskemaer, som måske kan aktiveres på tværs af genrer. Jensen betegner disse tolkningsskemaer som supertemaer, og et af disse fire supertemaer har særlig relevans for nærværende undersøgelse. Det drejer sig om temaet "Our little corner of the world“" dvs. et afkrogstema, der relaterer sig til såvel mentalt som socialt rum. Afkrogstemaet er det dominerende hos de danske seere i Bruhn Jensens undersøgelse (Jensen 1998:49), og udsigtet fra det danske univers giver sig udslag i tre gennemgående undertemaer: For det første tematiseres en dansk selvtilfredshed og for det andet tematiseres $i$ samme åndedrag en kritik af dansk selvtilstrækkelighed. Dansk underlegenhed er desuden et tredje undertema, der følges af det positive ved ikke at være noget særligt, idet trygheden og ufarligheden i den danske afkrog fremhæves.

Ved hjælp af afkrogstemaet kan de forestillinger om det amerikanske og det danske, som præger de danske seeres reception af de to serier, belyses mere overordnet. I begge undersøgelser udtrykkes opfattelser af USA og amerikanerne, og disse opfattelser er præget af en række uproblematiske selvmodsigelser. Det amerikanske bruges primært som en negativ baggrund, der fremhæver det positive ved Danmark og danskere. Den nationale selvtilfredshed kommer til udtryk i den ivrige fremhævelse af et omfattende moralsk forfald blandt amerikanere, hvor moralsk opløsning og psykisk elendig- 
hed florerer. Her spiller forestillingerne om amerikanernes ligegyldighed, når det drejer sig om beskyttelsen af egen ære og værdighed også en rolle, hvilket fungerer som forklaring på, at de kan få sig selv til at optræde i den amerikanske serie.

\begin{abstract}
Brit: det er jo selvfølgelig også svært for man ser jo USA, som sådan meget overfladisk, og bare du er kendt, så er det lige meget, hvad du er kendt for. Så derfor tror jeg måske mere, at det går derovre, (pause) nok også fordi danskere er sådan meget nede på jorden, der skal altså noget til, før vi sådan virkelig neeej! det er sådan lige med et gran salt og stille og roligt og ikke lige nogen grund til at fare i flint over det (Brit 18 år $\mathrm{HH}$, RL:16).
\end{abstract}

Men den danske selvtilfredshed er ikke helt uproblematisk, da angsten for at bliver offer for den sladder og stigmatisering, som kunne være resultatet at træde frem i medierne med sine problemer, er et væsentligt argument $\mathrm{i}$ den afvisning af det danske program, som kvinderne fremfører. Den trygge afkrog kan med andre ord også være hæmmende, da det er socialt farligt at vise sig frem. Men dette ubehag trumfes af, at det amerikanske rædselsscenarium også indholder en forestilling om, at USA og amerikanere er præget af moralsk puritanisme og forældede normer i kontrast til en dansk afslappethed, tolerance og progressivitet på specielt seksualmoralens område.

Michelle: Derovre har de jo meget med, at de helst skal være uskyldige, når de skal giftes og alt sådan noget. Altså det er der mange, der går op i, i hvert fald hvad jeg har forstået også igennem de pro- grammer (Michelle 23 år SoS, RL:6).

Afskyen for såvel moralisterne som for de moralsk fortabte, der præger oplevelsen af gæsterne i daytime talkshowet, gentages i den nationalkulturelle sammenligning, hvor det danske bliver synonym for den balance mellem de to ekstremer, som kan redde de værdifulde, men truede sociale relationer. Men selvom det er en meget positiv version af afkrogstemaet, der dominerer, så kommer temaet også til udtryk som en forklaring på den danske series utilstrækkelighed, idet dansk $t v$ 's underlegenhed i forhold til det amerikanske fremhæves:

Ane: Jeg ved egentlig ikke, jeg synes altid det falder til jorden, når det er dansk, der efterligner et eller andet amerikansk. Altså det bliver altid et flop, synes jeg (Ane 20 år HH, DNS:1).

På dette felt kunne man hævde, at hvad angår tv-produkter, så synes USA at fungere som målestok, og det bekræftes af, at den amerikanske serie for år tilbage sammen med andre amerikanske tv-produkter har været brugt i et statusdemonstrerende projekt for især HH-gruppen. At have kendskab til og adgang til de sidste $t v$-mæssige ekcesser fra amerikansk tv er vigtigt for denne gruppe.

\section{Medie- og genredifferentiering}

Resultaterne af receptionsundersøgelsen peger på, at den sociale nærhed ikke i sig selv er nok til at fastholde seernes interesse, hvis den følelsesmæssige nærhed og relevans, som seerne forventer af daytime talkshowet, ikke imødekommes af den nationale produktion. Seernes direkte erfaring med daytime talkshowgenren kunne dermed tænkes at sætte nogle rammer for nationale produktio- 
ner af kvalitativ karakter. Men daytime talkshowets status i hierarkiet inden for tv-genrer kunne være en forklaring på, hvorfor TvDanmark og redaktionen bag Det Ny Synnøve ikke syntes at beherske genren særlig godt. De vanskeligheder, som denne genre faktisk giver, og de mange færdigheder, den rent faktisk kræver, er analyseret på meget øjenåbnende vis af Laura Gindstaff (Grindstaff 1997). Hendes fremragende analyse af produktionsprocessen bag to forskellige amerikanske daytime talkshows fremviser med al ønskelig tydelighed, hvor mange menneskelige og økonomiske ressourcer denne tilsyneladende simple tv-genre kræver. Måske undervurderede TvDanmark simpelthen genren på grund af dens lavstatus. Men på baggrund af receptionsanalysen af daytime talkshowene er der meget der tyder på, at tv-producenterne skal beherske de tv-genrer, som seerne allerede har udviklede vurderingskriterier i forhold til. Producenterne må kort sagt være på udtryks- og indholdsmæssig omgangshøjde med de ikke-dansk producerede tilbud, som seerne har adgang til. På et mere generelt niveau betyder dette, at det kommunikative kredsløb mellem tv-producenter, programproduktioner og seerne bevæger sig $i$ en mere transnational og i den forstand global retning.

Men spørgsmålet er, om kulturel oprindelse i tv-produktioner i samme åndedrag mister betydning for seerne? Undersøgelsen af de danske kvinders oplevelse af det amerikanske og det danske daytime talkshow peger på, at der er tale om et ganske kompliceret forhold, som måske har med netop denne specifikke genres relation til publikum at gøre. Daytime talkshowet adskiller sig muligvis fra andre tv-genrer, når det drejer sig om den kulturelle oprindelses funktion i seeroplevelsen. Hvis man sammenligner med tv-fiktionens relation til seernes so- ciale virkelighed, så involverer daytime talkshowet både en realitetsprøvning (Höijer 1991), sådan som andre faktagenrer også gør, og daytime talkshowet involverer et brud med ære og værdighed hos deltagerne i form af selskabelighedsbruddene. Daytime talkshowet kan derfor være en mere provokerende form for skildring af danskere, som måske kan være sværere at forene med den nationalkulturelle selvforståelse end eksempelvis fiktionens, som har en anden realitetsstatus. Den kulturelle oprindelse skaber en social nærhed, som bliver til et dilemma i denne genre, og den er dermed muligvis et langt mere flertydigt tiltrækningsmiddel i forhold til seerne end den kulturelle oprindelses funktion i tv-fiktionen.

I forhold til tv-fiktion synes kulturel oprindelse på den ene side at være et langt mere entydigt tiltrækningsmiddel. F.eks. er det vanskeligt at forklare dansk tv-fiktions enorme succes blandt seerne alene med evnen til at realisere kendte tv-genrer eksempelvis politiserien eller hverdags-soapen på tilfredsstillende vis. Hvis vi ser på seertallene til danskproduceret super prime time tv-fiktion tilrettelagt for det brede publikum, så er henholdsvis soapen Taxa (DR1 97-99) og i særdeleshed politiserien Rejseholdet (DR1 2000-2002) nyere eksempler på, at genreproduktioner i en kombination med social nærhed synes at spille en afgørende rolle for seernes lyst til at se programmerne $^{10}$. Men på den anden side kunne det også se ud til, at kulturel oprindelse ikke hjælper på seertallene for super prime time tv-fiktion for det brede publikum, hvis genreforventningerne ikke imødekommes på en tilfredsstillende måde. De relativt beskedne seertal til soapen Hotellet (TV 2 2000+) kunne være et tegn på $\operatorname{det}^{11}$.

Sammenfattende kan undersøgelsen pege på behovet for og relevansen af en 
genremæssig tilgangsvinkel til analyser af $\mathrm{tv}$-mediets rolle i kulturelle globaliseringsprocesser. Den lokale og nationale forankring har en meget stor betydning i receptionen af den globale tv-kulturs genreformater. Det lokale og nationale bliver transformeret, men der er ikke tale om en bevidsthedsmæssig tilstand af kulturel hjemløshed hos respondenterne. Tværtimod styrkes deres oplevelse af danskhed og af at være danskere på sæt og vis samtidig med, at begge dele bliver sat i relief af det amerikanske. Men som undersøgelsens resultater også peger på, så spiller selve genreaspektet ved mediets tilbud til seerne en overordentlig stor rolle i receptionen. Seernes genremæssige kriterier og vurderinger kunne derfor med fordel og i højere grad inddrages i undersøgelserne af spørgsmål så som kulturel oprindelse, kulturel globalisering og transformation af det nationale og lokale end det for øjeblikket er tilfældet. Trods interessen for de elektroniske mediers - og i særdeleshed $t v^{\prime}$ s - rolle i kulturelle globaliseringsprocesser, som blandt andre præger mediesociologisk orienterede teoretikere som John Tomlinson (Tomlinson 1999 og 1997), så analyseres tv typisk på et overordnet og generaliserende niveau. Analyser af tv-mediets rolle i kulturelle globaliseringsprocesser må dog, for mig at se, tage højde for, at mediet for det første i sig selv er en transnational kommunikationsform, som kan tænkes at have en selvstændig kulturel status, idet publikum gennem daglig brug har opbygget en erfaring med mediets tilbud. Mediet indeholder for det andet en række genrer, som hver især sætter meget forskellige rammer for udtryk, dramaturgi og henvendelsesformer, som igen har betydning for indholdet $\mathrm{i}$ disse genrer og for relationen mellem genren og publikum. Dette relativt komplicerede forhold mellem medier, genrer og modtagere har endelig og i sidste in- stans kulturel betydning. Ved at tage et genremæssigt udgangspunkt bliver det sandsynligvis muligt at få en mere præcis og differentieret belysning af, hvad kulturel globalisering egentlig kunne tænkes at indebære og betyde, og dermed ville kulturanalysen i sidste instans få en styrket udsigelseskraft.

\section{Noter}

1. Betegnelsen daytime talkshow kan forekomme lidt sær i en dansk tv-sammenhæng, da Det Ny Synnøve f.eks. blev sendt i aftentimerne. Men betegnelsen fastholdes af praktiske årsager, da det er den, som tv-producenterne selv bruger og som litteraturen om genren bruger. En meget interessant og anbefalelsesværdig bog om genrens udvikling $i$ amerikansk tv analyseret ud fra en tekstanalytisk tilgangsvinkel, er Jane Shattucs The Talking Cure fra 1997.

2. I 1999 blev dagens Ricki Lake-afsnit genudsendt ved 23-tiden og igen den følgende dags formiddag. Seertalsoplysningerne er alene på basis af hovedudsendelsen kl. 17:15, da det er her sening af serien primært finder sted.

3. Det følgende er en til denne sammenhæng kortfattet præsentation af genren talkshow. For en mere udfoldet analyse af genren og argumentation for dens kendetegn kan jeg henvise til H. Bruun, 2000b. Pladsen i denne artikel tillader heller ikke en analyse af den amerikanske og den danske serie, men kan findes i rapporten Ricki Lake i Danmark, (2001), arbejdspapir nr. 6, Global Media Cultures.

4. Valget var begrundet med, at det individuelle interview giver nogle muligheder for at fastholde og udforske relationen mellem genren, de to serier og den enkelte seer, som eksempelvis fokusgruppen ikke giver i samme grad qua det store element af gruppedynamiske forhold samt interaktion inden for gruppen. Da sendetidspunktet for specielt Ricki Lake desuden er sidst på eftermiddagen, kunne serien formodes at skulle indgå i den enkeltes dagligdag på en sådan måde, at individuel sening ville være det typiske. Det viste sig da også netop at være tilfældet, og det betød, at den situation, som individinterviewet kunne gennemføres i var tæt på den almindelige se-situation i den 
enkeltes private omgivelser. Endelig var valget af individinterviewet begrundet med, at begge serier tilhører en tv-genre, som mange mener er placeret på de absolut nederste pladser i tv-mediets genrehierarki. Der kunne derfor være en trang til at distancere sig fra serierne, som ville kunne få lov at dominere i en fokusgruppe, hvor vægten vil være på betydningsdannelsens sociale aspekter. På grund af genrens lavstatus kunne den tryghed, det kunne give at være i egne omgivelser, derfor være væsentlig at styrke. At gøre intervieweren til gæst i den interviewedes hjem kunne tilmed tænkes at nedtone de associationer til smagsdommer, lærer og eventuel eksamen, som jeg i min egenskab af at være universitetsansat kunne tænkes at give anledning til, trods bevidste forsøg på at modarbejde disse fra min side.

5. Via kontakt med undervisere på de to skoler, et brev til eventuelt interesserede og på baggrund af telefonisk kontakt med potentielle deltagere blev der valgt ni kvinder ud af en bruttogruppe på 15. Kriterierne var, at man så Ricki Lake jævnligt og havde gjort det i gennem længere tid, dvs. jeg var ikke interesseret $\mathrm{i}$ at få rekrutteret deltagere, som bare gerne ville mene noget om serien uden at se programmerne. De skulle være "brugere“ $i$ et vis omfang. Rekrutteringen betød dog samtidig, at det ikke var en gruppe neutrale seere, som indgik i den komparative undersøgelse. Tværtimod var det en gruppe, som havde et vældig godt kendskab til serien, og på nær to var de meget glade for serien. At jeg i høj grad fik Ricki Lake-seriens "fan-klub" i tale på grund af min rekuttering har givetvis haft en afgørende betydning for vurderingen af den danske serie, idet Ricki Lake blev en form for målestok. På den anden side var det også det publikum, som den danske serie skulle forsøge at interessere, og serien blev i pressen op til premieren lanceret som et dansk Ricki Lake-program, hvilket de interviewede kvinder også havde bemærket. Sammenligningen var derfor relevant også at indbygge $i$ undersøgelsens design.

6. En redegørelse for interviewtekniske valg og for anvendelsen af datasammenfatningsmetoder kan læses i Bruun 2001.

7. For en langt mere udfoldet og nuanceret redegørelse for resultaterne af receptionsanalysen af henholdsvis Ricki Lake og Det Ny Synnøve henviser jeg til min rapport Ricki
Lake i Danmark (2001). I rapporten er der desuden en belysning af, hvilken betydning den sociale og aldersmæssige differentiering har. Af hensyn til omfanget af denne artikel har jeg prioriteret hovedresultaterne.

8. Kun to af respondenterne er inde på, at det nok i højere grad er selve programmet, som man bør kritisere og ikke gæsterne. Begge er fra HH-gruppen, og SoS-gruppen er generelt langt mere orienteret mod at placere skyld for konflikterne og konfrontationerne hos gæsterne, end $\mathrm{HH}$-gruppen er.

9. David Morley refererer til Scott K. Phillips undersøgelse fra 1986. Phillips viser i sin analyse af relationen mellem de "indfødte" og "tilflytterne" $\mathrm{i}$ en landsby i Yorkshire, at det at arbejde bevidsthedsmæssigt i den beskrevne dikotomi synes at være en fast kognitiv mekanisme, hvorimod brugen af dikotomien er både relativ og mobil, idet den er styret af aktuelle behov og konteksten. Morley konkluderer "While the distinction between these two groups is central to the life of the village it is, nontheless, a boundary which is both porous and mobile, and which is marked by the different people, in different ways, for different purposes, at different times. This boundary then, while important, is far from fixed" (Morley 2000:244).

10. De to serier har haft meget høje seertal. Taxa lå på et gennemsnit på 1,2 million og en share på $48,9 \%$. Rejseholdet, som fortsatte i efteråret 2001 og her i foråret 2002, har haft en gennemsnitlig rating på 1,6 million og en share på $67,2 \%$.

11. Serien har haft en gennemsnitlig rating på 762.000 og en share på 39\%. Selvom konkurrencen på det danske tv-marked gør det mere og mere vanskeligt at opnå meget høje seertal, så er det relativt beskedne tal for super prime time produktioner af den type, som serien tilhører.

\section{Litteratur}

Andersen, Johanne Sønderlund et al. 1999: Ricki Lake. Upubliceret studenteropgave i receptionsanalyse: Informations- og Medievidenskab Aarhus Universitet

Ang, Ien 1996: Living Room Wars. Rethinking Media Audiences for a Postmodern World. London: Routledge. 
Bruun, Hanne 2001: Ricki Lake i Danmark. Receptionen af et amerikansk og et dansk daytime talkshow. Arbejdspapir nr. 6. Film- og Medievidenskab, Københavns Universitet: forskningsprojektet Global Media Cultures, København.

Bruun, Hanne 2000a: „Go Ricki - om dramaturgi i konfrontative daytime talkshows". Retorik Magasinet nr. 10, 38.

Bruun, Hanne 2000b: „The Aesthetics of the Television Talk Show". Nordicom Review nr. 2, 21.

Bruun, Hanne 1999: Talkshowet. Portræt af en tv-genre. København: Borgens Forlag.

Dahl, Henrik 1997: Hvis din Nabo var en Bil. En bog om livsstil. København: Akademisk Forlag.

Gallup TV-Meter database.

Goffman, Erving 1967: Interaction Ritual. Essays on face-to-Face Behavior. New York: Penguin.

Grindstaff, Laura 1997: „Producing Trash, Class, and the Money Shot: A Behind-the-Scenes Account of Daytime TV Talk Shows", in: J. Lull \& S. Hinerman (eds.) Media Scandals. Oxford: Polity Press.

Gripsrud, Jostein 1992: „The Aesthetics and Politics of Melodrama", in: P. Dahlgren \& C. Sparks (eds.) Journalism and Popular Culture. London: Sage.

Hagen, Ingunn 1992: „News Viewing Ideals and Everyday Practices: The Ambivalens of Watching" Dagsrevyen. Bergen: University of Bergen.

Horton, Donald \& R. Richard Wohl 1956: „Mass Communications and Para-social Interaction". Psychiatry no. 3, 19. Höijer, Birgitta 1998: Det hörde vi allihåp!. Värnamo: Fälth \& Hässler.

Höijer Birgitta 1998: „Cognitive and Psycho-Dynamic Perspectives on Reception of Television Narration", in: B. Höijer \& A. Werner (eds.) Cultural
Cognition. New perspectives in audience theory. Gøteborg: Nordicom.

Höijer Birgitta 1996: Audiences' expectations on the interpretations of different television genres: A socio-cognitive approach, Paper til IAMCR-konference, Sydney, 18.-22. august.

Höijer, Birgitta 1991: Lustfylld glömska, kreativ illusion och realitetsprövning. Om publikens tankeprocesser vid tittande på fiktion och fakta. Stockholm: Sveriges Radio, nr. 15.

Jensen, Klaus Bruhn (ed.) 1998: News of the World. World cultures look at television news. London: Routledge

Jensen, Johan Fjord 1981: „Myter" Efter Guldalderkonstruktionens Sammenbrud. Århus: Modtryk.

Jessen, Anne Dorthe et al. 2000: Det Ny Synnøve. Upubliceret studenteropgave i receptionsanalyse: Informationsog Medievidenskab, Aarhus Universitet.

Katz E. \& T. Liebes 1990: The Export of Meaning. Cross-cultural readings of Dallas. New York: Oxford University Press.

Krüger, Udo Michael 1998: „Thementrends in Talkshows der 90er Jahre“. Media Perspektiven, nr. 12.

Kvale, Steinar 1994: InterView. København:Hans Reitzels Forlag.

Lindlof, Thomas R. 1995: Qualitative Communication Research Methods. London: Sage.

Moran, Albert 1998: Copycat TV. Globalisation, program Formats and Cultural Identity. Luton: University of Luton Press.

Morley, David 2000: Home Territories. Media, Mobility and Identity. London: Routledge.

Rose, Brian G. 1985: „The Talkshow" in Brian G, Rose (ed.) TV Genres. A Handbook and a Reference Guide. New York: Greenwood Press. 
Shattuc, Jane M. 1997: The Talking Cure TV Talk Shows and Women. New York: Routledge.

Simmel, Georg 1910: "Sociability“, in Donald L. Levine (ed.) Georg Simmel. On Individuality and Social Forms. 1971. Chicago: The University of Chicago Press.

Skovmand, Michael 1992: „Barbarous TV international: syndicated Wheels of Fortune", in: Schrøder, Kim \& Skovmand, Michael (eds.) Media Cultures.
Reappraising Transnational Media. London: Routledge.

Tomlinson, John 1999: Globalization and Culture. Oxford: Polity Press.

Tomlinson, John 1997: „Cultural Globalization and Cultural Imperialism", in: Mohammadi, Ali (ed.) International Communication and Globalization. London: Sage.

Winnicott, Donald W. 1971/1990: Leg og Virkelighed. København: Hans Reitzels Forlag. 